\title{
A Scrutiny on the Aggression Levels of the Students of Sports, Vocational, and Anatolian High Schools
}

\author{
Mehmet ALTIN ${ }^{1} \&$ Ali Osman KIVRAK ${ }^{2}$ \\ ${ }^{1}$ Recreation Department, Sports Sciences Faculty, Selcuk University, Konya, Turkey \\ ${ }^{2}$ Department of Coaching Education, Sports Sciences Faculty, Selcuk University, Konya, Turkey \\ Correspondence: Mehmet ALTIN, Sports Sciences Faculty, Recreation Department, Konya, Turkey. E-mail: \\ mealtin@selcuk.edu.tr
}

Received: March 14, 2018

Accepted: April 28, 2018

Online Published: July 28, 2018

doi:10.5539/ies.v11n8p69

URL: https://doi.org/10.5539/ies.v11n8p69

\begin{abstract}
The objective has been set through this study to present and compare the aggression levels in three different High School types. The population of the study was constituted by the High School students in the province of Konya and its sampling group by the 226 male and 190 female students studying at Vocational High Schools, Anatolian High Schools, and Sports High Schools. In the study, demographic personal information form was used in the collection of personal information and Buss-Perry Aggression Scale (BPAS), which was developed by Buss and Perry (1992), whose the validity and reliability study in its Turkish form was performed by Demirtaş-Mardan (2013), was used for determining the aggression levels. In terms of the anger dimension depending on the gender factor, no statistical change was observed, while it was determined that the average values for the male students in the physical aggression, hostility, and verbal aggression dimensions were higher than the female students and such changes were statistically significant $(\mathrm{P}<0.05)$. It can be said on the basis of the findings of this study that the aggression values of the Secondary Education students did not vary in line with the sportive activities and that the male students have more sense of aggression than female students.
\end{abstract}

Keywords: secondary education, aggression, vocation, sports, student

\section{Introduction}

At all the schools in the world, problems regarding aggression and terror incidents are being experienced and the people do nothing but watch the extent of the destruction and damages of aggression. In particular, the United States was shaken due to news about the armed assaults in 17 schools in 2018 and resulting fatalities. It appears to be highly difficult to find the source of the aggression that make students angry in such high levels and that is carried to physical dimension as to taken the lives of other people. Such assaults do not remain at school levels and the incidents relating to aggression and terrorism are increasing rapidly in all the countries of the world.

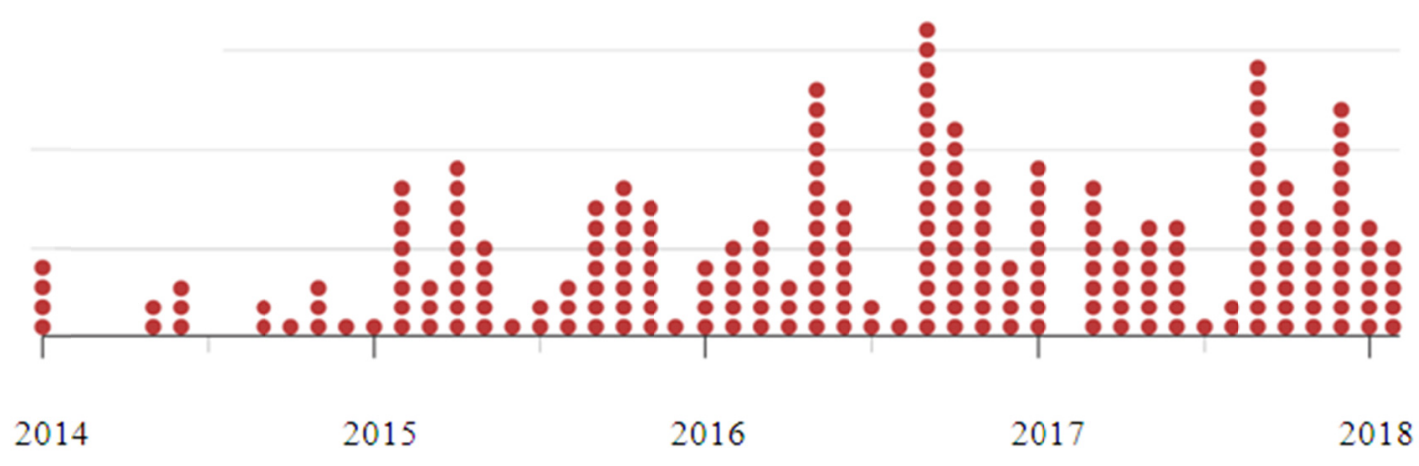

Figure 1. Increase in the school attacks in the US as per years (http://www.gunviolencearchive.org/)

It appears that the incidents of aggression and violence have been gradually increasing in the recent years in our 
country as in other countries. In addition to the prevention of the educational activities, there is the inability to control the sense of anger and aggression in the educational institutions. Despite the fact that the existence of the problem has been identified and numerous studies in different fields and dimensions have been conducted in regards to the issue, the aggression factor has not been solved yet.

Koç and Büyükgöze-Kavas (2015) considered the behaviors that contain willful action and that aim to inflict damage as aggression and they did not take the behaviors that were not shown deliberately into account as aggression. In defining aggression, Bandura (1973) expressed it as the behavior resulting with posing personal damage and the damage incurred by property. We see that aggression is frequently used as to mean damaging and harming others (Cox, 1985; Baron, 1977; Perlman \& Cozby, 1983; Anderson \& Bushman, 2002; Ballard, Rattley, Fleming, \& Ashley, 2004). K. Gergen and M. Gergen (1986) state that aggression is not merely behavioral and emotional elements like anger, hostility, and bursting accompany it. It is observed that the sense of aggression might remain inside the person or take place as a factor that inflicts damage on the surroundings (Fromm, 1993). Cüceloğlu (2016) has specified that aggression can be oriented to an object, an event, a situation, a person, or the society as well as the individual itself.

Despite the fact that there are many studies relating to aggression within the literature, unfortunately, the results of physical and psychological aggressiveness can be so destructive that they cannot be rectified and that, inability to solution aside, they become inextricable. Even if the source of the aggression disappears, its impact continues in individuals and might pose damage on the person himself/herself and the surroundings. Bandura and Ross (1961) reported that children become aggressive by being impressed by the aggressive behaviors of the adults. Avc1 (2006) underlined that the anger levels of family members of the adolescents with violence-oriented behavior is high. In addition to family education, the endeavors regarding the control of anger, violence, and aggression that will be supported by educational factors can reduce the issue to lower levels. Young ones might turn into the individuals that are mechanical, senseless, and without social responsibility when only information-oriented education is provided and the benchmarks of success and failure are indexed to a mere diploma or certificates.

Aronson, Wilson, and Akert (2005) state that abnormality in the central nervous system and endocrine system, hormonal irregularities, brain damages, and neuropsychological factors, as well as gene combinations can cause aggression. Individual and gene-related hormonal differences and changes can have impacts on such biological processes. One of the biggest properties distinguishing humans from other living beings is the emotions. (Pizaro \& Salovey, 2002) specified that emotions act as an intermediary assisting the judgment system by means of steering thoughts potentially toward the right direction. Garnefski and Kraaij (2006) stated that individuals develop cognitive emotional arrangement strategies following the incidents that they experience or become subject to and such situation helps them to manage their emotions. It is a requirement to include cognitive studies in educational dimensions in order to keep the destructive dimensions of the sense of aggression at a controllable level.

Each age group has its own characteristics and some age groups are important for controlling the instincts like anger, violence, and aggression in individuals. In particular, the 14-18 age group is named as the age of adolescence and a highly critical period in terms of aggression control. Tekgül, Dirik, Karademirci, Bıçakçı, and Öngel (2012) referred to this period as a the period of transitioning into life in which physical and sexual development and psychosocial maturation take place and social factors have the highest importance for individuals in their development periods. This period corresponds to the second stage of secondary education; it is a reality that the students studying in educational institutions with different types and learning areas have different affections and reactions. Each problem in the adaptation of young ones into life might inflict deep wounds within the social structure. It must never be forgotten that the youth with sensitiveness and responsibility will shed light to and become the guarantee of our future. Berkowitz (1993) state that majority of the youth groups use aggression to have their names heard and protect their status within the entourage.

Within the literature, it is specified regarding aggression that individuals do not consider the rights of others and respect them and might use the methods of violence and forcefulness in order to have their thoughts accepted by others (Tutkun, Güner, Ağaoğlu, \& Soylu, 2010; Hasta \& Güler, 2013). Many different approaches can be encountered within the literature when it comes to the source and cause of aggression; it is observed that the term is classified and grouped in different ways like active, passive, physical, instrumental, relational, emotional, defensive and destructive, containing hostility, direct or indirect, proactive-reactive, verbal, or antisocial aggression (Fromm, 1993; Cox, 1985; Wiehe, 1998; Ainsworth, 2002; Kirsh, 2006; Wrangham, 2017; Lansford, 2018). Fredman, Sears, and Carlsmith (1989) distinguished aggression into three as prosocial, antisocial, and sanctioned aggression, while Moeller (2001) deemed it appropriate to scrutinize it under two headings as physical and verbal aggression. Regardless of the type and classification manner of aggression, the characteristic of the results appearing are always the same. Aggression can be directed to the objects and individuals behaving or 
situated inside the impact area physically or appear at the level of anger, hostility, and verbal assault. The pungent or obdurate talking toward the counterparty can be replaced by the senses of anger and hostility in the course of time.

The behaviors caused by aggression at schools might appear as a highly variable structure. In addition to the possibility of self-damage by individuals, it might be observed in such a large range of verbal or physical behavior that might be oriented to friends or the attendants of the school, or even the people situated around the school. Gangs can be constituted within the circle of friends and it might turn into different destructive behaviors like threatening with guns, use of alcohol or drugs, molestation, rape, or threatening. It is possible to encounter numerous studies; in which, in addition to the individual or collective fights, the incidents of aggression like carrying sharp tools, pushing, mocking, nicknaming, insult, bad language, and threatening are reported (Miller, 1994; Yavuzer, Gündoğdu, \& Dikici, 2009; Durmuş \& Gürgan, 2005; Eke \& Ögel, 2006; Moeller, 2001; Kapç1, 2004).

The objective of the study is to scrutinize and identify the changes in the aggression levels of the Vocational High School, Anatolian High School, and Sports High School students. The educational factors must be focused on more in view of the emotions and behaviors of anger, violence, and aggression of our youth in a scheduled and systematical manner at our schools that have a very important place for the students. We wish it to shed light in the subsequent studies in different dimensions and scopes.

\section{Material and Method}

\subsection{Research Design}

The objective has been set through this study to present and compare the aggression levels in three different High School types. The population of the study was constituted by the secondary education students in the province of Konya and its sampling group by total 416 students, being 226 male and 190 female students, studying at Vocational High Schools, Anatolian High Schools, and Sports High Schools.

\subsection{Data Collection Tool}

In the study, demographic personal information form was used in the collection of personal information and Buss-Perry Aggression Scale (BPAS), which was developed by Buss \& Perry (1992), whose the validity and reliability study in its Turkish form was performed by Demirtaş-Mardan (2013), was used for determining the aggression levels. This scale adapted by Buss and Perry from the Buss-Durke Hostility Scale is a five Likert type scale consisting of 29 articles. In the scale, the articles numbered 13, 8, 2, 11, 25, 16, 29, 22, and 23 constitute the physical aggression subscale; the articles numbered 27, 6, 21.14, and 4 constitute the verbal aggression subscale; the articles numbered 20,24, 3, 26, 10,15, 7, and 17 constitute the hostility subscale; and the articles numbered 19 , $28,1,18,9,23,12$ constitute the anger subscale. The articles numbered 9 and 16 of the scale were scored with reverse coding. The Cronbach alpha internal internal consistency coefficient obtained for the entire scale was specified as 0.85 , alpha value obtained for physical aggression as 0.78 , alpha value obtained for verbal aggression as 0.48 , alpha value obtained for anger as 0.76 , and alpha value obtained for hostility as 0.71 .

\subsection{Statistical Analysis}

For this study, Cronbach's Alpha value was calculated as 0.86 . By testing the normality of the data and homogeneousness of the variances, Independent Sample t test was used in pairwise comparisons, One-Way ANOVAs was used in multiple comparisons, Tukey HSD test was used in determining the source of the difference, and Pearson correlation analysis was used in identifying the correlation between the dimensions.

\section{Results}

Table 1. Aggression changes in terms of gender factor

\begin{tabular}{|c|c|c|c|c|c|c|c|c|c|c|}
\hline \multirow{2}{*}{ Gender } & \multirow{2}{*}{$\mathrm{n}$} & \multirow{2}{*}{$\%$} & \multicolumn{2}{|c|}{ Physical Aggression } & \multicolumn{2}{|c|}{ Anger } & \multicolumn{2}{|c|}{ Hostility } & \multicolumn{2}{|c|}{ Verbal Aggression } \\
\hline & & & $\mathrm{x}$ & Ss & $\mathrm{x}$ & Ss & $\mathrm{x}$ & Ss & $\mathrm{x}$ & Ss \\
\hline Male & 226 & 54.3 & 22.16 & 2.73 & 18.37 & 2.74 & 20.49 & 2.51 & 13.02 & 2.49 \\
\hline \multirow[t]{3}{*}{ Female } & 190 & 45.7 & 21.54 & 2.83 & 18.26 & 2.71 & 19.52 & 2.42 & 12.08 & 2.48 \\
\hline & $\mathrm{t}$ & & \multicolumn{2}{|c|}{2.272} & \multicolumn{2}{|c|}{.407} & \multicolumn{2}{|c|}{3.992} & \multicolumn{2}{|c|}{3.837} \\
\hline & $\mathrm{p}$ & & \multicolumn{2}{|c|}{$.023 *$} & \multicolumn{2}{|c|}{.684} & \multicolumn{2}{|c|}{$.000 *$} & \multicolumn{2}{|c|}{$.000 *$} \\
\hline
\end{tabular}

\footnotetext{
* Significant Difference among the groups.
} 
In the scrutiny of Table 1, no statistical change in the anger sub-dimension on the basis of the gender factor is observed; the average value of the male students in the physical aggression dimension was found higher (22.16 \pm 2.73) than those $(21.54 \pm 2.83)$ of the female students and it was determined that such change is statistically significant $(\mathrm{p}<0.05)$. In the dimension of hostility the value $(20.49 \pm 2.51)$ for the males was higher than the value $(19.52 \pm 2.42)$ of the females and it was determined that such change is statistically significant $(\mathrm{p}<0.05)$. In the dimension of verbal aggression, the average value (13.02 \pm 2.49$)$ for the males was higher than that $(12.08 \pm 2.48)$ of the females and it was determined that such change is statistically significant.

Table 2. Aggression changes in terms of sportive activity factor

\begin{tabular}{|c|c|c|c|c|c|c|c|c|c|c|}
\hline \multirow[t]{2}{*}{ Doing Sports } & \multirow[t]{2}{*}{$\mathrm{n}$} & \multirow[t]{2}{*}{$\%$} & \multicolumn{2}{|c|}{$\begin{array}{c}\text { Physical } \\
\text { Aggression }\end{array}$} & \multicolumn{2}{|c|}{ Anger } & \multicolumn{2}{|c|}{ Hostility } & \multicolumn{2}{|c|}{ Verbal Aggression } \\
\hline & & & $\mathrm{x}$ & Ss & $\mathrm{x}$ & Ss & $\mathrm{x}$ & Ss & $\mathrm{x}$ & Ss \\
\hline Doing Sports & 211 & 50.7 & 22.09 & 2.64 & 18.09 & 2.65 & 19.86 & 2.51 & 12.52 & 2.62 \\
\hline Not Doing Sports & 205 & 49.3 & 21.66 & 2.93 & 18.56 & 2.79 & 20.24 & 2.51 & 12.66 & 2.43 \\
\hline \multicolumn{3}{|c|}{$\mathrm{t}$} & \multicolumn{2}{|c|}{1.561} & \multicolumn{2}{|c|}{-1.764} & \multicolumn{2}{|c|}{-1.530} & \multicolumn{2}{|c|}{-.553} \\
\hline \multicolumn{3}{|c|}{$\mathrm{p}$} & \multicolumn{2}{|c|}{.119} & \multicolumn{2}{|c|}{.078} & \multicolumn{2}{|c|}{.127} & \multicolumn{2}{|c|}{.580} \\
\hline
\end{tabular}

As can be seen in Table 2, it was determined that the changes in the aggression dimensions on the basis of the factor of doing sports are not statistically significant.

Table 3. Aggression changes in terms of school type factor

\begin{tabular}{|c|c|c|c|c|c|c|c|c|c|c|}
\hline \multirow{2}{*}{ Education Level } & \multirow{2}{*}{$\mathrm{n}$} & \multirow{2}{*}{$\%$} & \multicolumn{2}{|c|}{ Physical Aggression } & \multicolumn{2}{|c|}{ Anger } & \multicolumn{2}{|c|}{ Hostility } & \multicolumn{2}{|c|}{ Verbal Aggression } \\
\hline & & & $\mathrm{x}$ & Ss & $\mathrm{x}$ & Ss & $\mathrm{x}$ & Ss & $\mathrm{x}$ & Ss \\
\hline $\begin{array}{c}\text { Vocational High } \\
\text { School }\end{array}$ & 148 & 35.6 & 21.70 & 2.93 & 17.85 & $2.79^{b}$ & 19.82 & $2.63^{b}$ & 12.47 & 2.41 \\
\hline $\begin{array}{c}\text { Anatolian } \\
\text { High School }\end{array}$ & 112 & 26.9 & 21.79 & 2.86 & 18.83 & $2.75^{\mathrm{a}}$ & 19.77 & $2.32^{\mathrm{b}}$ & 12.81 & 2.62 \\
\hline $\begin{array}{c}\text { Sports } \\
\text { High School }\end{array}$ & 156 & 37.5 & 22.10 & 2.59 & 18.39 & 2.59 & 20.46 & $2.49^{\mathrm{a}}$ & 12.54 & 2.57 \\
\hline Total & 416 & 100 & 21.88 & 2.79 & 18.32 & 2.73 & 20.05 & 2.51 & 12.59 & 2.53 \\
\hline \multicolumn{3}{|c|}{$\mathrm{F}$} & \multicolumn{2}{|c|}{.870} & \multicolumn{2}{|c|}{4.266} & \multicolumn{2}{|c|}{3.434} & \multicolumn{2}{|c|}{.624} \\
\hline \multicolumn{3}{|c|}{ p } & \multicolumn{2}{|c|}{.420} & \multicolumn{2}{|c|}{$.015^{*}$} & \multicolumn{2}{|c|}{$.033^{*}$} & \multicolumn{2}{|c|}{.536} \\
\hline
\end{tabular}

*, $a b=$ Significant Difference among the groups.

As can be seen in Table 3, in terms of the school type factor, no change is observed in the physical and verbal aggression dimensions and it was determined that in the anger dimension, the averages $(18.83 \pm 2.75)$ of the Anatolian High School students are higher than those (17.85 \pm 2.79$)$ of the Vocational High School students and that such change is statistically significant $(\mathrm{p}<0.05)$. It was determined that the averages $(20.46 \pm 2.49)$ of the Sports High School students was higher than those (19.82 \pm 2.63$)$ of the Vocational High School students and those of the (19.77 \pm 2.32$)$ Anatolian High School students and that such change is statistically significant. 
Table 4. Aggression changes in terms of grade and income factor

\begin{tabular}{|c|c|c|c|c|c|c|c|c|c|c|}
\hline \multirow[t]{2}{*}{ Grade Level } & \multirow[t]{2}{*}{$\mathrm{n}$} & \multirow[t]{2}{*}{$\%$} & \multicolumn{2}{|c|}{ Physical Aggression } & \multicolumn{2}{|c|}{ Anger } & \multicolumn{2}{|c|}{ Hostility } & \multicolumn{2}{|c|}{$\begin{array}{c}\text { Verbal } \\
\text { Aggression }\end{array}$} \\
\hline & & & $\mathrm{x}$ & Ss & $\mathrm{x}$ & Ss & $\mathrm{x}$ & Ss & $\mathrm{x}$ & Ss \\
\hline $9^{\text {th }}$ Grade & 169 & 40.6 & 21.45 & $2.75^{\mathrm{b}}$ & 18.34 & 2.70 & 19.99 & 2.55 & 12.99 & $2.62^{\mathrm{a}}$ \\
\hline $10^{\text {th }}$ Grade & 193 & 46.4 & 22.17 & $2.84^{\mathrm{a}}$ & 18.22 & 2.74 & 20.02 & 2.59 & 12.21 & $2.38^{b}$ \\
\hline $11^{\text {th }}$ Grade & 54 & 13.0 & 22.18 & $2.58^{\mathrm{a}}$ & 18.57 & 2.79 & 20.35 & 2.09 & 12.69 & 2.60 \\
\hline \multicolumn{3}{|c|}{$\mathrm{F}$} & \multicolumn{2}{|c|}{3.347} & \multicolumn{2}{|c|}{.362} & \multicolumn{2}{|c|}{.457} & \multicolumn{2}{|c|}{4.489} \\
\hline \multicolumn{3}{|c|}{$\mathrm{p}$} & \multicolumn{2}{|c|}{$.036^{*}$} & \multicolumn{2}{|c|}{.697} & \multicolumn{2}{|c|}{.633} & \multicolumn{2}{|c|}{$.012 *$} \\
\hline \multirow{2}{*}{ Income Level } & \multirow{2}{*}{$\mathrm{n}$} & \multirow{2}{*}{$\%$} & \multicolumn{2}{|c|}{ Physical Aggression } & \multicolumn{2}{|c|}{ Anger } & \multicolumn{2}{|c|}{ Hostility } & \multicolumn{2}{|c|}{ Verbal Aggression } \\
\hline & & & $\mathrm{x}$ & Ss & $\mathrm{x}$ & Ss & $\mathrm{x}$ & Ss & $\mathrm{x}$ & Ss \\
\hline $500-1500 \mathrm{TL}$ & 80 & 19.2 & 21.58 & 2.89 & 18.15 & 2.57 & 19.65 & 2.61 & 12.34 & 2.35 \\
\hline $1501-2500 \mathrm{TL}$ & 189 & 45.4 & 22.03 & 2.74 & 18.51 & 2.81 & 19.96 & 2.55 & 12.72 & 2.60 \\
\hline $2501-3500 \mathrm{TL}$ & 51 & 12.3 & 22.37 & 2.73 & 18.00 & 2.38 & 20.06 & 2.23 & 12.39 & 2.50 \\
\hline Above $3501 \mathrm{TL}$ & 96 & 23.1 & 21.56 & 2.81 & 18.24 & 2.86 & 20.54 & 2.45 & 12.64 & 2.54 \\
\hline \multicolumn{3}{|c|}{$\mathrm{F}$} & \multicolumn{2}{|c|}{1.442} & \multicolumn{2}{|c|}{.680} & \multicolumn{2}{|c|}{1.99} & \multicolumn{2}{|c|}{.559} \\
\hline \multicolumn{3}{|c|}{$\mathrm{p}$} & \multicolumn{2}{|c|}{.230} & \multicolumn{2}{|c|}{.565} & \multicolumn{2}{|c|}{.115} & \multicolumn{2}{|c|}{.643} \\
\hline
\end{tabular}

*, $\mathrm{a} \mathrm{b}^{\mathrm{*}}$ Significant Difference among the groups.

According to Table 4, no statistical change in the anger and hostility sub-dimensions in line with the grade factor was observed. It was determined that in the physical aggression dimension, the averages $(21.45 \pm 2.75)$ of the students in $9^{\text {th }}$ grade were higher than those $(22.17 \pm 2.84)$ of the students in $10^{\text {th }}$ grade and those $(22.18 \pm 2.58)$ of the students in $11^{\text {th }}$ grade and that such change is statistically significant $(\mathrm{p}<0.05)$. In the verbal aggression dimension, the change between the average value $(12.99 \pm 2.62)$ for the $9^{\text {th }}$ grade and the average value $(12.21 \pm$ $2.38)$ for the $10^{\text {th }}$ grade was determined to be statistically significant $(\mathrm{p}<0.05)$. No statistically significant change was observed among the students, in the aggression sub-dimensions in terms of income level.

Table 5. Aggression changes in terms of parents' education factor

\begin{tabular}{|c|c|c|c|c|c|c|c|c|c|c|}
\hline \multirow{2}{*}{ Father Education Level } & \multirow{2}{*}{$\mathrm{n}$} & \multirow{2}{*}{$\%$} & \multicolumn{2}{|c|}{ Physical Aggression } & \multicolumn{2}{|c|}{ Anger } & \multicolumn{2}{|c|}{ Hostility } & \multicolumn{2}{|c|}{ Verbal Aggression } \\
\hline & & & $\mathrm{x}$ & Ss & $\mathrm{x}$ & Ss & $\mathrm{x}$ & Ss & $\mathrm{x}$ & Ss \\
\hline Primary Education & 141 & 33.9 & 22.16 & 2.67 & 18.01 & 2.68 & 20.23 & 2.67 & 12.73 & 2.60 \\
\hline Secondary Education & 122 & 29.3 & 21.91 & 2.87 & 18.23 & 2.93 & 19.85 & 2.50 & 12.43 & 2.47 \\
\hline Higher Education & 124 & 29.8 & 21.77 & 2.85 & 18.44 & 2.63 & 20.14 & 2.45 & 12.57 & 2.55 \\
\hline $\begin{array}{c}\text { Master/ } \\
\text { Doctorate }\end{array}$ & 29 & 7.0 & 20.79 & 2.61 & 19.62 & 2.13 & 19.62 & 2.03 & 12.62 & 2.38 \\
\hline $\mathrm{F}$ & & & \multicolumn{2}{|c|}{2.00} & \multicolumn{2}{|c|}{2.961} & \multicolumn{2}{|c|}{.815} & \multicolumn{2}{|c|}{.301} \\
\hline $\mathrm{p}$ & & & \multicolumn{2}{|c|}{.112} & \multicolumn{2}{|c|}{.32} & \multicolumn{2}{|c|}{.486} & \multicolumn{2}{|c|}{.824} \\
\hline \multirow{2}{*}{ Mother Education Level } & \multirow{2}{*}{$\mathrm{n}$} & \multirow{2}{*}{$\%$} & \multicolumn{2}{|c|}{ Physical Aggression } & \multicolumn{2}{|c|}{ Anger } & \multicolumn{2}{|c|}{ Hostility } & \multicolumn{2}{|c|}{ Verbal Aggression } \\
\hline & & & $\mathrm{x}$ & Ss & $\mathrm{x}$ & Ss & $\mathrm{x}$ & Ss & $\mathrm{x}$ & Ss \\
\hline Primary Education & 188 & 45.2 & 21.85 & 2.66 & 18.38 & 2.68 & 19.88 & 2.33 & 12.42 & 2.54 \\
\hline Secondary Education & 152 & 36.5 & 21.80 & 2.82 & 18.14 & 2.84 & 20.18 & 2.59 & 12.83 & 2.66 \\
\hline Higher Education & 68 & 16.3 & 22.21 & 3.15 & 18.56 & 2.51 & 20.34 & 2.84 & 12.54 & 2.08 \\
\hline $\begin{array}{c}\text { Master/ } \\
\text { Doctorate }\end{array}$ & 8 & 1.9 & 21.13 & 2.03 & 18.25 & 3.73 & 19.13 & 2.30 & 12.38 & 3.11 \\
\hline $\mathrm{F}$ & & & \multicolumn{2}{|c|}{.555} & \multicolumn{2}{|c|}{.427} & \multicolumn{2}{|c|}{1.085} & \multicolumn{2}{|c|}{.762} \\
\hline $\mathrm{p}$ & & & \multicolumn{2}{|c|}{.645} & \multicolumn{2}{|c|}{.734} & \multicolumn{2}{|c|}{.355} & \multicolumn{2}{|c|}{.516} \\
\hline
\end{tabular}

When Table 5 is examined, no statistically significant difference was observed in the aggression score averages of the secondary education students in terms of the educational levels of the parents. 
Table 6. The correlation values observed in the aggression sub-dimensions

\begin{tabular}{|c|c|c|c|c|c|}
\hline \multirow{2}{*}{\multicolumn{2}{|c|}{ Sub-dimensions }} & \multirow{3}{*}{$\begin{array}{c}\text { Physical Violence } \\
1\end{array}$} & \multirow{3}{*}{$\begin{array}{l}\text { Anger } \\
-.024\end{array}$} & \multirow{3}{*}{$\begin{array}{c}\text { Hostility } \\
.036\end{array}$} & \multirow{3}{*}{$\begin{array}{c}\text { Verbal Aggression } \\
-.076\end{array}$} \\
\hline & & & & & \\
\hline \multirow{3}{*}{ Physical Violence } & Pearson Correlation & & & & \\
\hline & Sig. (2-tailed) & & .622 & .461 & .123 \\
\hline & $\mathrm{N}$ & 416 & 416 & 416 & 416 \\
\hline \multirow{3}{*}{ Anger } & Pearson Correlation & -.024 & 1 & $.158 * *$ & -.019 \\
\hline & Sig. (2-tailed) & .622 & & .001 & .692 \\
\hline & $\mathrm{N}$ & 416 & 416 & 416 & 416 \\
\hline \multirow{3}{*}{ Hostility } & Pearson Correlation & .036 & $.158^{* *}$ & 1 & .076 \\
\hline & Sig. (2-tailed) & .461 & .001 & & .124 \\
\hline & $\mathrm{N}$ & 416 & 416 & 416 & 416 \\
\hline \multirow{3}{*}{ Verbal Aggression } & Pearson Correlation & -.076 & -.019 & .076 & 1 \\
\hline & Sig. (2-tailed) & .123 & .692 & .124 & \\
\hline & $\mathrm{N}$ & 416 & 416 & 416 & 416 \\
\hline
\end{tabular}

**. Correlation is significant at the 0.01 level (2-tailed).

As can be seen in Table 6, it was determined that the change in the sense of hostility of the secondary education students are in connection with the sense of anger and that the changes are statistically significant $(\mathrm{p}<0.01)$.

\section{Discussion}

While no statistical change in the anger dimension in line with the gender factor is observed, it was determined that the average values of the male students in the dimensions of physical aggression, hostility, and verbal aggression are higher than the female students and that such changes are statistically significant $(\mathrm{P}<0.05)$. Karataş $(2008)$ reported in the study regarding the aggression and anger levels of the students in the same age and grades that the physical aggression scores of the male students are higher than the females. Buntanie and Costenbader (1997) stated that the males exhibited more physical violence indications when they get angry. Aggression that does not remain only at the school desks and environment settles in the focus of the lives of adolescents in the subsequent periods and has impact on their life quality. There are many of studies where the aggression averages of males were found higher than females (Tambağ \& Öz, 2005; A.Y archeski, Mahon, \& T. Yarcheski, 2002; C. Arslan, Hamarta, E. Arslan, \& Saygın, 2010; Efilti, 2006; De Wied, Branje, \& Meeus, 2007; Halıcı \& Baran, 2006; Çelik, Zengin, \& Baş, 2017). The results of those studies are important as they are in parallel with the findings of our study. It is possible to encounter studies showing no difference between females and males as well within the literature even if they are not many (Ağlamaz, 2006; Çobanoğlu, 2005; Kurtyılmaz, 2005). It is reported that the males demonstrate their anger more than the females and that the females experience them more internally (Zhou, Eisenberg, Wang \& Reiser, 2004). It must be remembered that such changes among the females and males will vary in terms of numerous socio-cultural, economic, psychological, and sociological factors. As Navaro (2000) reports, males are taught to be aggressive and competitive while females are taught to be warm and supportive to males in their lives, their children, and each other. Despite the fact that males and females get angry in equal frequency, there are social restrictions in the expression of anger by females (Eagly \& Steffen, 1986). Prentice and Carranza (2002) state that the traditional social norms for the gender roles are closely related with the power inequality between females and males.

It was observed that the higher the grade levels of the students, the lower their aggression scores would become, that the physical and verbal aggression values of the students of the $9^{\text {th }}$ grade were higher than other grades, and that such change was statistically significant $(\mathrm{p}<0.05)$. Karataş $(2008)$ determined significant differences in the physical, verbal aggression and anger scores on the basis of the grade level factor and reported that the aggression scores of the students in the $10^{\text {th }}$ grade as lower than those of the $9^{\text {th }}$ and $11^{\text {th }}$ grades. Campano and Munakata (2004) determined in their study in which they examined the aggression and anger scores in terms of grade levels that the aggression scores of the final year students was higher than the students in other grades. Studies where no aggression change as per grade level was found can also be encountered (Ağlamaz, 2006; Bolat-Karataş, 2002). The findings of the foregoing study and those of ours varied as the value for the $9^{\text {th }}$ degree in our study was found higher than other two grades. The reasons for such differentiation can be the start of the students in an educational level that they have never known and become used to, their lack of orientation, and environmental and personal factors. It can be said that especially the higher level of physical and verbal aggression arises from the instinct of the students to adapt themselves to the new condition and to protect themselves.

In consideration of the secondary education type, no difference was observed in the physical and verbal aggression 
dimensions, while the average value of the Anatolian High School students in the anger dimension was higher than the values of the Vocational High School students and the average values of Sports High School was higher than other schools in the hostility dimension and it was determined that such differentiations were statistically significant $(\mathrm{P}<0.05)$. In each level of the educational system, the students must be steered as to make the most suitable educational choices for them. When they are excluded from their areas of interests, abilities, and proclivities, difficulties will take place and students will be pushed to finish an educational level mandatorily in addition to being educated in a field that they do not want. Karataş (2008) observed statistically significant differences in the sub-dimension of aggression of High School students in terms of the field of study they choose. Exhibition of aggression indirectly, not physically and verbally, is the situations where the action of aggression is mainly not shown but experienced internally. Accordingly, the findings of Karataş (2008) and those of ours are supportive of each other. Durmuş and Gürgan (2005) report that the aggression incidents most frequently observed in the High School students is inflicting damages on the tables and chairs of the school deliberately $(70.9 \%)$ and involving with the fights outside school causing injury in the students (70.1\%). In the same study, they state that there are statistical differences in the events of seeing a friend carrying a tool like a knife, knuckles, skewers, sticks, chains, etc. when going to school, in line with the school type. At schools, all kinds of manifestations must be observed, recorded, and analyzed. Committing the offense with small and simple tools and overlooking the behavior are the predecessors of greater explosions of aggression in the continuation of their development periods. Simple and bitter words might turn into insults and a small pencil into a gun.

Ağlamaz (2006) determined significant changes in the aggression scores of High School students that differ in line with the school type. The number of the studies regarding the direct impact of the school type on aggression is not very high. The unique structure of the society and educational institutions, their culture and pattern can be considered as the determinant of such situation. In addition to school type, the analysis conducted in view of the state of taking part in sportive activities by the students, no significant change was observed between the students doing sports and the students not doing sports. Şahin (2003) states that the desire for aggression does not discharge by means of sports; on the contrary, such desire increase more and more. While sportive activities are required to affect aggression as an instinct that can be controlled, the factors like the social structure and sports culture might have exactly opposite impact.

Karataş (2008) found a significant positive relation between anger and aggression. Gündoğdu (2010) reported that significant positive and negative relations between anger and aggression had been determined. Presence of the sense of anger together with the sense of hostility in individuals might cause possible increases that might be encountered subsequently in the physical and verbal aggression dimensions. The correlation observed in the anger and hostility dimensions in our study (table 6: $\mathrm{p}<0.05$ ) is valuable as it is similar to those studies.

On the basis of the findings of this study, it is possible to say that the aggression values of the secondary education students in terms of the sportive events do not statistically differ and that the male students have higher-level sense of aggression than the female students. In particular, the fact that the male students' averages of hostility and physical and verbal aggression are higher than female students invokes the opinion that aggression might reach destructive and irreparable dimensions. Jarvinen (2006) states that a child might tend to behaviors of aggression by being impressed by his/her peers in line with the environmental factors and that the aggression can be put under control at an early age through the education of the parents in this regard. We must take the necessary precautions in order to ensure that the instinct of aggression can remain as a controllable innocent emotion before reaching destructive dimensions inside our children and youth. There are numerous studies the behavioral dimensions of aggression and anger can be improved and their control is ensured through the education, management, and control programs. The study of M. Ando, Asakura, S. Ando \& Simons-Morton, (2007) regarding the prevention of aggressive behaviors consists of four-week programs for problem-solving, stress management, and communication skills. They reported that at the end of the program, there became a positive increase in the relations of the students with their classmates and a manifest decrease in their aggressive behaviors. Genç (2007) reported that in the High School students to whom they provided anger control training, there became no change in the control group and that there became a significant reduction in the students' constant anger, anger inside, and anger outside levels in the experiment group and a significant increase in their levels of controlling their anger. Yorgun (2007) stated that in the $9^{\text {th }}$ and $10^{\text {th }}$ grade High School students that they educated in terms of violence management and anger control (16 sessions and $50 \mathrm{~min}$ ) was efficient in the in the reduction of violent behaviors and ensuring anger control. As can be seen from the results of the study, thanks to the training, management, and control programs regarding the instinct of aggression, its destructive power weakens and it becomes possible to minimize the damage on the individual and his/her surroundings.

Turgut, Lagace, İzmir, and Dursun (2006) reported that a moderate-level relation between mental illness and 
violence is present and that the highest violence ratios are observed in the individuals with substance abuse and antisocial personality disorder. Social structure, sociological status, and incidents are significant factors in the explosions of aggression. A trivial and vitriolic word, an action of pushing that seem to be innocent, or a stare containing violence, which are slurred over by forgiving within the system, can cause incidents that make the hearts of the entire society bleed if not controlled at the source and the violence incidents at schools using small paraphernalia or weaponry of crime concerning a few persons can grow and become destructive to the extent that they might cause public indignation and chaos. It can be said that the secondary education students exhibited statistical variance in the aggression sub-dimensions according to the fields of education, gender, and classroom level and doing sports and parents' education and income levels do not have impact on the aggression behavior in this study. It is contemplated that implementation of larger and more comprehensive studies and taking the required educational precautions are more of a requirement than a suggestion in order not to allow the instincts like anger, violence, and aggression to come up with more destructive results.

\section{References}

Ağlamaz, T. (2006). A scrutiny on the aggressions scores of the high school students in terms of self revelation behavior, school type, gender, class level, mother-father education level, and monthly income level of the family (Unpublished Postgraduate Thesis). 19 Mays University Social Sciences Institute, Samsun.

Ainsworth, P. B. (2002). Psychology and Policing. In L. Johnston, F. Leishman, \& T. Newburn (Eds.), Cullompton. Devon: Willan Publishing.

Anderson, C. A., \& Bushman, B. J. (2002). Human Aggression. Annual Review of Psychology, 53, $27-51$. https://doi.org/10.1146/annurev.psych.53.100901.135231

Ando, M., Asakura, T., Ando, S., \& Simons-Morton, B. (2007). A psychoeducational program to prevent aggressive behavior among Japanese early adolescents. Health Education \& Behavior, 34(5), 765-776. https://doi.org/10.1177/1090198106291965

Aronson, E., Wilson, T. D., \& Akert, R. B. (2005). Social psychology (5th ed.). Pearson Education International.

Arslan, C., Hamarta, E., Arslan, E., \& Saygin, Y. (2010). A Scrutiny on the Aggression and Interpersonal Problem Solving among Adolescents. Illköğretim Online, 9(1), 379-388.

Avc1, R. (2006). A scrutiny on the functions as a family of the adolescents who exhibit the behavior of violence and the adolescents who do not exhibit the behavior of violence in view of anger and anger expression styles (Unpublished postgraduate thesis). Çukurova University Social Sciences Institute, Adana.

Ballard, M. E., Rattley, K. T., Fleming, W. C., \& Ashley, P. K. (2004). School Aggression and Dispositional Aggression among Middle School Boys. Research in Middle Level Education Online, 271, 1-11. https://doi.org/10.1080/19404476.2004.11658163

Bandura, A. (1973). Institutionally sanctioned violence. Journal of Clinical Child Psychology, 2, 23-24. https://doi.org/10.1080/15374417309532525

Bandura, A., Ross, O. F., \& Ross, S. A. (1961). Transmission of Aggression through Imitation of Aggressive Models. Journal of abnormal and social psychology, 63(3), 575-582, https://doi.org/10.1037/h0045925

Baron, R. A. (1977). Human Aggression. New York, Plenum. https://doi.org/10.1007/978-1-4615-7195-7

Berkowitz, L. (1993). Aggression: Its causes, consequences, and control. New York: McGraw-Hill Book Company. https://doi.org/10.1002/10982337(1994)20:6<464::AIDAB2480200608>3.0.CO;2-9

Bolat-Karataş, Z. (2002). A scrutiny on the relation between the mother-father aggression and the aggression of high school students (Unpublished postgraduate thesis). Çukurova University Social Sciences Institute, Adana.

Buntaine, R. L., \& Costenbader, V. K. (1997). Self-reported differences in the experience and expression of anger between girls and boys. Sex Roles, 36, 625-637. https://doi.org/10.1023/A:1025670008765

Buss, A.H., \& Perry, M. (1992). The Aggression Questionnaire. J. Pers. Soc. Psych, 63, 452-4599, https://doi.org/10.1037/0022-3514.63.3.452

Campano, J. P., \& Munakata, T. (2004). Anger and aggression among Filipino Students. Adolescence, 39(156), 757-764.

Çelik, A., Zengin, S., \& Baş, M. (2017). Determining The Level Of Aggression In Athletes High School Students. Gaziantep University Journal of Sport Science, 2(2), 20-31. 
Çobanoğlu, Ş. (2005). Mobbing; Emotional Assault at Workplace and Methods of Dealing. Timaş Publications Psychology Series, 34-35.

Cox, R.H. (1985). Sport psychology. Dubuque, lowo: Wm.C. Brown

Cüceloglu, D. (2016). Humans and their Behavior: basic concepts of psychology (28th ed.). Remzi Publishing, Istanbul.

De Wied, M., Branje, S. J. T., \& Meeus W. H. J. (2007). Empathy and conflict resolution in friendship relations among adolescents. Aggressive Behavior, 33, 48-55. https://doi.org/10.1002/ab.20166

Demirtaş-Mardan, H. A. (2013). A study on the validity and reliability of the Turkish form of the Buss-Perry aggressions scale. Turkish Psychiatry Journal, 23.

Durmuş E., \& Gürgan, U. (2005). Tendencies of High School Students toward Violence and Aggressions. Turkish Educational Sciences Journal, 3(3), 253-269.

Eagly, A., \& Steffen, V. J. (1986). Gender and aggressive behavior: A meta-analytic review of the social psychological literature. Psychological Bulletin, 100, 309-330. https://doi.org/10.1037/0033-2909.100.3.309

Efilti, E. (2006). A Scrutiny on the Aggression, Control Focus and Personality Properties of the Students Studying in the Secondary Education Institutions in Comparison (Doctoral thesis, Selçuk University, Konya).

Eke, C. Y., \& Ögel, K. (2006). Prevalence of the crime and violence in. the schools in Istanbul 1st Violence and School: Symposium on Violence against Children at Schools and their Surroundings and the Precautions that can be taken. MEB, UNICEF, Istanbul.

Freedman, J. L., Sears, D. O., \& Carlsmith, J. M. (1989). Social Psychology (Translated by: Ali Dönmez). Istanbul: Ara Publications.

Fromm, E. (1993). Origins of the Destructiveness in Humans. Şükrü Alpagut (Trans., 2nd ed.). Istanbul: Payel.

Garnefski, N., \& Kraaij, V. (2006). Relationships between cognitive emotion regulation strategies and depressive symptoms: A comparative study of five specific samples. Personality and Individual Differences, 40, 1659-1669. https://doi.org/10.1016/j.paid.2005.12.009

Genç, H. (2007). Impact of the group anger control training on the constant anger levels of the high school 9th grade students (Unpublished postgraduate thesis). Dokuz Eylül University. Educational Sciences Institute, Izmir.

Gergen, K. J., \& Gergen, M. M. (1986). Social Psychology (2nd ed., p. 226). New York: Springer-Verlag. https://doi.org/10.1007/978-1-4615-7866-6

Gündoğdu, R. (2010). A scrutiny on the levels of conflict resolution, anger and aggression of the classroom students in terms of some variables. ÇÜ Social Sciences Institute Journal, 19(3), 257-276.

Halıc1, P., \& Baran, G. (2006). A Scrutiny on the Aggression Tendencies of the 12-14-year-old Children who Study at Boarding Primary Education Regional Schools and who Live with their Families. Judicial Psychiatry Journal, 3(2), 23-30.

Hasta, D., \& Güler M. E. (2013). Aggressions: A Scrutiny in terms of Interpersonal Relation Styles and Empathy. Ankara University Social Sciences Institute Journal, 4(1). Retrieved from http://dergiler.ankara.edu.tr/dergiler/49/1775/18772.pdf

Jarvinen, L. K. (2006). Aggressive behaviour and social problem-solving strategies: a review of the findings of a seven-year follow-up from childhood to late adolescence. Criminal Behaviour and Mental Health, 11, 236-250. https://doi.org/10.1002/cbm.398

Kapçı, E. G. (2004). Relation of the Type and Frequency of being subject to Bullying by Primary Education Students on Depression, Anxiety, and Self-esteem. Ankara University E.B.F. Journal, 37(1), 1-13. https://doi.org/10.1501/Egifak_0000000087

Karataş, Z. (2008). Anger and Aggressions in High School Students. Ç.Ü. Social Sciences Institute Journal, $17(3)$.

Kirsh, S. J. (2006). Children, Adolescents, and Media Violence: A Critical Look at the Research. London: Sage Publications. https://doi.org/10.4135/9781452204253

Koç, B., \& Büyükgöze-Kavas, A. (2015). A scrutiny on the relations of the university students regarding 
aggressions, interpersonal problem solving skills, manners of interpersonal relations, and communication skills. International Turkish Literature Culture Education Journal, 4(2), 783-799. https://doi.org/10.7884/teke.491

Kurtyllmaz, Y. (2005). Relations between the aggressions levels of prospective teachers and their academic achievements, communication and problem solving skills (Eskisehir: Unpublished postgraduate thesis).

Lansford, J. E. (2018). Development of aggression. Current Opinion in Psychology, 19, 17-21. https://doi.org/10.1016/j.copsyc.2017.03.015

Miller, G. E. (1994). School violence miniseries impressions and implications. School Psychology Review, 23(2), 257-261.

Moeller, T. G. (2001). Youth Aggression and Violence: A Psychological Approach. London: Lawrence Erlbaum Associates.

Navaro, L. (2000). A Witch Tale: On anger, power, and sexual roles (4th ed.). Istanbul: Remzi Publishing.

Perlman, D., \& Cozby, C. P. (1983). Social Psychology. New York, N.Y.: Rinehortand Winston.

Pizarro, D. A., \& Salovey, P. (2002). On being and becoming a good person: The role of emotional intelligence in moral development and behavior. In J. Aronson (Ed.), Improving academic achievement: Impact of psychological factors on education (pp. 247-266). San Diego: Academic Press. https://doi.org/10.1016/B978-012064455-1/50015-4

Prentice, D. A., \& Carranza, E. (2002). What women should be, shouldn't be, are allowed to be, and don't have to be: The contents of prescriptive gender stereotypes. Psychology of Women Quarterly, 26(4), 269-281, https://doi.org/10.1111/1471-6402.t01-1-00066

Şahin, H. M. (2003). Violence and Aggressions in Sports. Nobel Publication Distribution. Ankara.

Tambağ, H., \& Öz, F. (2005). Manner of expressing anger of the adolescents living with their families and in orphanages. Crisis Journal, 13(1), 11-21. https://doi.org/10.1501/Kriz_0000000216

Tekgül, N., Dirik, N., Karademirci, E., Bıçakçı, B., \& Öngel, K. (2012). Assessment on the Knowledge and Attitudes of Adolescent Parents on Adolescence. Tepecik Training Hospital Journal, 22(1), 59-62.

Turgut, T., Lagace, D., Izmir, M., \& Dursun, S. (2006). Assessment on the violence and aggression in psychiatry clinics: diagnostic approaches. Clinical Psychopharmacology Bulletin, 16(3), 179-194.

Tutkun, E., Güner, B. Ç., Ağaoğlu, S. A., \& Soylu, R. (2010). Assessment on the Aggression Levels of the Sportspeople doing Team Sports and Individual Sports. Sports and Performance Studies Journal, 1(1), 23-29. https://doi.org/10.4135/9781452232003

Wiehe, V. R. (1998). Understanding Family Violence: Treating and Preventing Partner, Child, Sibling, and Elder Abuse. London: Sage Publications, Inc. https://doi.org/10.4135/9781452232003

Wrangham, R. W. (2017). Two types of aggression in human evolution. PNAS, 115(2) 245-253. https://doi.org/10.1073/pnas.1713611115

Yarcheski, A., Mahon, N., \& Yarcheski, T. (2002). Anger in early adolescent boys and girls with health manifestations. Nursing Research, 51, 229-236. York: Holt, Reinhart and Winston. https://doi.org/10.1097/00006199-200207000-00003

Yavuzer, Y., Gündoğdu, R., \& Dikici, A. (2009). Teachers' perceptions about school violence in one Turkish city. Journal of School Violence, 8(1), 29-41. https://doi.org/10.1080/15388220802067797

Yorgun, A. (2007). The Effect of Violence Management Training on Violent Behaviors and Anger Control of Secondary School Students (Unpublished postgraduate thesis). ODTÜ Social Sciences Institute, Ankara.

Zhou, Q., Eisenberg, N., Wang, Y., \& Reiser, M. (2004). Chinese children's effortful control and dispositional anger/frustration: Relations to parenting styles and children's social functioning. Developmental Psychology, 40, 352-366. https://doi.org/10.1037/0012-1649.40.3.352

\section{Copyrights}

Copyright for this article is retained by the author(s), with first publication rights granted to the journal.

This is an open-access article distributed under the terms and conditions of the Creative Commons Attribution license (http://creativecommons.org/licenses/by/4.0/). 